\title{
PERSEPSI TENTANG MATA PELAJARAN AKUNTANSI DAN PERHATIAN ORANG TUA TERHADAP PRESTASI BELAJAR SISWA MAN TEMPEL
}

\author{
Oleh : \\ Triyani Budi Utami ${ }^{1}$ \\ Pardiman $^{2}$
}

\begin{abstract}
Abstrak
Penelitian ini bertujuan untuk mengetahui: (1) Pengaruh Persepsi Siswa tentang Mata Pelajaran Akuntansi terhadap Prestasi Belajar Akuntansi Siswa kelas XI IPS MAN Tempel Tahun Ajaran 2012/2013, (2) Pengaruh Perhatian Orang Tua terhadap Prestasi Belajar Akuntansi Siswa kelas XI IPS MAN Tempel Tahun Ajaran 2012/2013, (3) Pengaruh Persepsi Siswa tentang Mata Pelajaran Akuntansi dan Perhatian Orang Tua secara bersama-sama terhadap Prestasi Belajar Akuntansi Siswa kelas XI IPS MAN Tempel Tahun Ajaran 2012/2013. Penelitian ini merupakan penelitian ex post facto dan populasi karena seluruh siswa dijadikan sebagai subjek penelitian, yaitu sebanyak 79 siswa. Teknik pengumpulan data menggunakan angket untuk variabel Persepsi Siswa tentang Mata Pelajaran Akuntansi dan Perhatian Orang Tua, sedangkan dokumentasi digunakan untuk mengumpulkan data tentang Prestasi Belajar Akuntansi. Kedua data tersebut telah diuji validitas dan reliabilitasnya. Uji prasyarat analisis menggunakan uji linearitas dan uji multikolinearitas. Pengujian hipotesis pertama dan ke dua menggunakan regresi sederhana, sedangkan untuk pengujian hipotesis ke tiga menggunakan regresi ganda. Hasil penelitian menunjukkan bahwa: (1) terdapat pengaruh positif dan signifikan Persepsi Siswa tentang Mata Pelajaran Akuntansi terhadap Prestasi Belajar Akuntansi, dibuktikan $r_{x 1 y}=0,459, r^{2} \times 1 y=$ 0,210 , thitung $(4,528)>t_{\text {tabel }}(1,994)$, (2) terdapat pengaruh positif dan signifikan Perhatian Orang Tua terhadap Prestasi Belajar Akuntansi, dibuktikan $\mathrm{r}_{\mathrm{x} 2 \mathrm{y}}=0,378$, $r^{2}{ }_{x 2 y}=0,143$, thitung $(3,585)>t_{\text {tabel }}(1,994)$, (3) terdapat pengaruh positif dan signifikan Persepsi Siswa tentang Mata Pelajaran Akuntansi dan Perhatian Orang Tua secara bersama-sama terhadap Prestasi Belajar Akuntansi, dibuktikan $\mathrm{R}_{\mathrm{y}(1,2)}=$ $0,558, R_{y(1,2)}^{2}=0,312, F_{\text {hitung }}(17,209) F_{\text {tabel }}(3,13)$. Penelitian ini menunjukkan besarnya sumbangan relatif dari variabel Persepsi Siswa tentang Mata Pelajaran Akuntansi 60,95\%, Perhatian Orang Tua 39,05\%, sedangkan sumbangan efektif variabel Persepsi Siswa tentang Mata Pelajaran Akuntansi sebesar 19,02\% dan variabel Perhatian Orang Tua 12,18\%.
\end{abstract}

Kata kunci: Persepsi tentang Mata Pelajaran Akuntansi, Perhatian Orang Tua, Prestasi Belajar.

\footnotetext{
${ }^{1}$ Alumni Prodi Pendidikan Akuntansi Fakultas Ekonomi Universitas Negeri Yogyakarta

${ }^{2}$ Staf Pengajar Jurusan P. Akuntansi Fakultas Ekononi Universitas Negeri Yogyakarta
} 


\begin{abstract}
The aims of this research are to know the influence of: (1) Student Perceptions of Subjects Accounting toward Student's Learning Achievement on Accounting at Grade XI IPS MAN Tempel Year 2012/2013, (2) Parents' Attention toward Student's Learning Achievement on Accounting at Grade XI IPS MAN Tempel Year 2012/2013, and (3) both Student Perceptions of Accounting Subjects and Attention Parent's together toward student's Learning Achievement on Accounting at Grade XI IPS MAN Tempel Year 2012/2013. This research is ex post facto and due to the entire student population is used as the subject of research, as many as 79 students. Techniques for data collection using a questionnaire variables Student Perceptions of Accounting Subjects and Attention Parents, whereas the documentation used to collect data on learning achievement Accounting. Both of these data have been tested for validity and reliability. Test requirements analysis using a linearity test and multicollinearity test. Testing of the first and second hypothesis using simple regression, whereas for the third hypothesis testing using multiple regression. The results of this research shows that there are: (1) positive and significant influence of student perceptions Subject Accounting toward Learning Achievement on Accounting, it proven by $r_{x l y}=$ $0.459, r_{x 1 y}^{2}=0.210$, thitung (4.528)> $t_{\text {table }}$ (1.994), (2) positive and Significant influence of Attention Parents toward Learning Achievement on Accounting, it proven by $r_{x 2 y}=0.378, r_{x 2 y}^{2}=0.143$, thitung $(3,585)>t_{\text {table }}(1.994)$, (3) positive and significant influence of both Student Perceptions Subject Accounting and Attention Parents toward Learning Achievement on Accounting, it proven by $R_{y(1,2)}=0.558, R_{y(1,2)}^{2}=0.312, F_{\text {hitung }}$ (17.209) $F_{\text {table }}(3,13)$. This research shows the rate of relative contribution from Student Perceptions Subject Accounting variable 60,95\%, Attention Parents 39,05\%, whereas effective contribution from Student Perceptions Subject Accounting variable are 19,02\% and variable Attention Parents are 12,18\%.
\end{abstract}

Key words: Perception of Subjects Accounting, Attention Parents, Learning Achievement.

\title{
A. Pendahuluan
}

Pendidikan yang baik adalah investasi jangka panjang suatu negara, oleh karena itu, mencerdaskan seluruh kehidupan bangsa dijadikan salah satu tujuan nasional yang wajib diperjuangkan oleh seluruh pihak. Dari tujuan nasional tersebut, tampak bahwa Indonesia menaruh harapan besar terhadap pendidikan karena pendidikan akan membentuk keseluruhan aspek pada diri seseorang sehingga menjadi manusia yang unggul dan berkualitas.

Berdasarkan UU No. 20 Tahun 2003 Pasal 1 ayat (1) tentang Sistem Pendidikan Nasional. Pendidikan adalah usaha sadar dan terencana untuk mewujudkan suasana belajar dan proses pembelajaran agar peserta didik secara aktif mengembangkan potensi dirinya untuk memiliki kekuatan spiritual keagamaan, pengendalian diri, kepribadian, kecerdasan, akhlak mulia, serta keterampilan yang diperlukan dirinya, masyarakat, bangsa dan negara. 
Perwujudan nyata dari pelaksanaan pendidikan di Indonesia adalah kegiatan pembelajaran di sekolah-sekolah formal, informal maupun nonformal. Kemajuan yang dicapai siswa dalam pendidikan yang ditempuh salah satunya dilihat dari prestasi belajar yang diraih merupakan cerminan ketercapaian tujuan pembelajaran berdasarkan penilaian dan evaluasi dari hasil belajar siswa. Jika siswa memiliki prestasi belajar yang baik, maka dapat dikatakan bahwa siswa telah memahami ilmu yang dipelajari sehingga diharapkan ilmu yang dimilikinya tersebut mampu mengasah potensi dirinya. Sebaliknya, apabila prestasi belajar yang diraih siswa buruk, potensi yang dimilikinya kurang dapat berkembang karena hal ini berarti bahwa ilmu yang diperoleh dalam proses belajar mengajar belum dapat diserap siswa dengan baik.

Sekolah Menengah Atas (SMA) atau Madrasah Aliyah (MA) telah menerapkan sistem penjurusan bagi siswa yang duduk di kelas XI di bangku SMA/MA. Biasanya jurusan di SMA/MA adalah IPS, IPA, Bahasa, Agama, atau jurusan keterampilan lainnya yang terdapat di sekolah masing-masing. Begitu pula di MAN Tempel terdapat jurusan IPS, IPA, dan Agama. Dalam penelitian ini hanya memfokuskan pada jurusan IPS saja, lebih khususnya kelas XI IPS MAN Tempel. Hal ini berfokus pada mata pelajaran Akuntansi yang ditempuh siswa kelas XI jurusan Ilmu Pengetahuan Sosial (IPS). Mata pelajaran Akuntansi merupakan salah satu mata pelajaran yang akan diujikan pada Ujian Akhir Nasional. Hal ini menyebabkan siswa perlu memahami lebih dalam tentang mata pelajaran Akuntansi dan tuntutan Prestasi Belajar Akuntansi di atas standar yang telah ditetapkan sekolah, sehingga beban siswa pun menjadi lebih besar.

"Prestasi belajar adalah kemampuan-kemampuan yang dimiliki siswa setelah ia menerima pengalaman belajarnya" (Nana Sudjana, 2004: 22). Prestasi belajar Akuntansi adalah hasil yang dicapai siswa melalui kegiatan belajar Akuntansi dengan memperoleh kemampuan kognitif, afektif, dan psikomotorik yang berhubungan dengan Akuntansi yang dinyatakan dalam bentuk penilaian skor atau angka. "Dengan diadakan penilaian maka siswa dapat mengetahui sejauh mana telah berhasil mengikuti pelajaran yang diberikan oleh guru" (Suharsimi, 2009: 6). Selain itu siswa juga dapat menunjukkan kemampuan belajar siswa yang dapat digunakan oleh pihak lain untuk mengambil keputusan.

Secara umum terdapat dua faktor yang mempengaruhi prestasi belajar akuntansi yaitu faktor intern dan faktor ekstern. Faktor intern berupa faktor jasmaniah dan faktor psikologis, seperti persepsi, minat, motivasi, dan sebagainya, sedangkan faktor ekstern berupa pengaruh dari keluarga, sekolah, dan masyarakat. Seperti yang telah dijelaskan oleh Slameto (2010: 54-71) "Faktor-faktor yang mempengaruhi belajar siswa dapat digolongkan menjadi dua, yaitu faktor intern, seperti faktor jasmaniah, faktor psikologis, faktor kelelahan. Faktor ekstern, yaitu seperti faktor keluarga, faktor sekolah dan faktor masyarakat". Apabila faktor-faktor tersebut terbentuk kuat pada diri siswa, prestasi belajar yang memuaskan dapat terjadi. Sebaliknya, jika faktorfaktor tersebut tidak diperhatikan dan tidak berjalan optimal maka prestasi belajar siswa akan sulit untuk mencapai tingkat yang diharapkan.

Prestasi Belajar Akuntansi yang dicapai siswa MAN Tempel khususnya kelas XI IPS dipengaruhi beberapa faktor, salah satunya adalah persepsi. 
Menurut Bimo Walgito (2010: 99) "Persepsi adalah suatu proses yang didahului oleh proses penginderaan, yaitu merupakan proses diterimanya stimulus oleh individu melalui alat indera atau juga disebut proses sensoris". Persepsi negatif siswa dimana mereka menganggap bahwa mata pelajaran Akuntansi merupakan suatu pelajaran yang sulit sehingga siswa kurang bersemangat untuk mengikuti pelajaran Akuntansi. Persepsi positif tentang mata pelajaran akuntansi perlu dimiliki oleh siswa. Dengan adanya persepsi bahwa suatu mata pelajaran itu mudah dimengerti dan menyenangkan untuk dipelajari maka kegiatan belajar siswa akan berjalan lancar. Bahkan saat latihan yang diberikan sudah lebih kompleks dan aplikatif, siswa akan tetap mampu mengerjakannya jika sudah ada perasaan senang dan tertantang untuk menyelesaikan latihan pada mata pelajaran tersebut.

Faktor ekstern yang mempengaruhi Prestasi Belajar Akuntansi siswa kelas XI IPS MAN Tempel adalah lingkungan sosial siswa yakni Orang Tua yang berupa Perhatian orang tua yang sangat dibutuhkan siswa dalam menumbuhkan sikap siswa dan mempengaruhi aktivitas belajar siswa. Dalam UU No. 20 Tahun 2003 pasal 7 ayat (1) "Orang tua berhak berperan serta dalam memilih satuan pendidikan dan memperoleh informasi tentang perkembangan pendidikan anaknya." Perhatian Orang Tua tercermin dari adanya bantuan yang diberikan orang tua kepada anak ketika anak mengalami kesulitan belajar yang berdampak pada prestasi belajar anak ke depannya. Selain itu, Perhatian Orang Tua dapat pula diwujudkan dengan menyediakan fasilitas pembelajaran yang dibutuhkan siswa guna mendukung proses belajar mengajarnya, yang juga akan berdampak pada prestasi belajar siswa. Kadang siswa tidak memiliki semangat, disinilah peran orang tua untuk memberikan perhatian kepada anaknya berupa motivasi dan semangat.

Berdasarkan hasil observasi penelitian ini terhadap siswa MAN Tempel khususnya kelas XI IPS pada bulan Juli-September 2012, dalam proses pembelajaran masih banyak siswa yang belum mencapai Kriteria Ketuntasan Minimal (KKM) yakni sebesar 72, sehingga siswa harus mengikuti ujian perbaikan. Dilihat dari siswa yang belum mencapai KKM sebanyak 38\% dari seluruh siswa kelas XI IPS MAN Tempel, yakni jumlah seluruh siswa tersebut adalah 79 siswa. Hal ini juga terlihat dari proses pembelajaran pada saat di kelas, beberapa siswa kelas XI IPS mengeluhkan bahwa mata pelajaran Akuntansi adalah mata pelajaran yang sulit. Padahal siswa tersebut belum lama mempelajari Akuntansi karena baru mendapatkan mata pelajaran Akuntansi pada saat kelas XI. Beberapa siswa mengeluhkan pula bahwa mata pelajaran Akuntansi itu membosankan. Persepsi-persepsi awal siswa tentang mata pelajaran Akuntansi yang negatif ini berdampak pada pencapaian prestasi belajar yang kurang optimal. Selain itu, siswa-siswi MAN Tempel juga memiliki problem dengan perhatian orang tua mereka yakni orang tua tidak memberikan sanksi ketika siswa tidak belajar, kurang memberikan kebebasan kepada siswa, dimana siswa harus memenuhi keinginan orang tua meskipun tidak sesuai dengan keinginannya sendiri, dan orang tua kurang memberikan perhatian saat siswa mengalami kesulitan belajar. Seringkali saat siswa belajar di rumah orang tuanya menonton TV atau mendengarkan radio sehingga menganggu konsentrasi belajar. Hal lain yakni siswa kurang adanya semangat untuk belajar, terlihat pada saat pelajaran siswa cenderung pasif tidak ada 
respon dengan apa yang sedang dipelajari. Masalah lainnya yakni masih minimnya fasilitas media pembelajaran yang digunakan oleh guru dalam menyampaikan materi pelajaran. Guru cenderung menyampaikan materi secara klasikal, keterbatasan media pembelajaran yang disediakan oleh sekolah, seperti LCD yang hanya digunakan oleh orang-orang tertentu saja, karena hanya ada 2 buah LCD saja. Selain itu juga masih ada guru yang kurang menguasai media pembelajaran yang ada.

Persepsi negatif siswa tentang mata pelajaran Akuntansi sangat mempengaruhi dalam pencapaian prestasi belajar Akuntansi. Para siswa MAN Tempel beranggapan bahwa mata pelajaran Akuntansi itu sulit dan membosankan, dan kurang mengetahui pengertian atau gambaran tentang mata pelajaran Akuntansi itu seperti apa, karena baru mendapatkan pelajaran Akuntansi di kelas sebelas sehingga menyimpulkan bahwa pelajaran Akuntansi seperti halnya pelajaran matematika yang penuh dengan hitungan, angka dan rumus-rumus. Siswa-siswi MAN Tempel sendiri lebih mengutamakan pelajaran Agama dibandingkan mata pelajaran umum seperti mata pelajaran Akuntansi, dikarenakan sekolah MAN Tempel adalah sekolah di bawah naungan Departemen Agama yang tentunya lebih memperbanyak dan mengutamakan tentang pelajaran Agamanya.

Perhatian orang tua dalam mendidik anak di lingkungan keluarga sangatlah penting karena lingkungan keluarga adalah tempat terbaik untuk memulai pendidikan. Dalam lingkungan keluarga kesempatan belajar dapat dimanfaatkan untuk mengembangkan bakat anak. Semua orang tua mempunyai tanggung jawab yang mulia untuk memberikan pendidikan jasmani, mental, dan pendidikan rohani. Inilah yang menjadi tujuan setiap orang tua supaya memberi jaminan dalam perkembangan anaknya. Orang tua mempunyai pengaruh yang sangat besar terhadap keberhasilan anak dalam belajar. Untuk meningkatkan prestasi belajar anak, orang tua harus mendidik anaknya secara keseluruhan. Bagi orang tua yang sadar mengenai pentingnya pendidikan anak di dalam keluarga akan membuat orang tua merasa terpanggil untuk mendidik anak-anaknya sejak kecil demi mengembangkan segala potensi yang masih terpendam dalam diri mereka, sehingga Perhatian Orang Tua perlu dipaparkan lebih lanjut untuk melihat sejauh mana Perhatian Orang Tua mempengaruhi prestasi belajar Akuntansi siswa.

Berdasarkan uraian yang telah dipaparkan sebelumnya, dapat disimpulkan bahwa Persepsi Siswa tentang Mata Pelajaran Akuntansi dan Perhatian Orang Tua mempunyai pengaruh terhadap keberhasilan belajar/prestasi belajar siswa khususnya pada mata pelajaran Akuntansi, oleh karena itu peneliti tertarik untuk melakukan penelitian dengan judul "Pengaruh Persepsi Siswa tentang Mata Pelajaran Akuntansi dan Perhatian Orang Tua terhadap Prestasi Belajar Akuntansi Siswa Kelas XI IPS MAN Tempel Tahun Ajaran 2012/2013".

\section{Pengertian Prestasi Belajar Akuntansi}

Menurut Slameto (2010: 2), "Belajar adalah suatu proses usaha yang dilakukan seseorang untuk memperoleh suatu perubahan tingkah laku yang baru secara keseluruhan, sebagai hasil pengalamannya sendiri dalam interaksi dengan lingkungannya", sedangkan menurut Sugihartono dkk 
(2007: 74), "Belajar adalah suatu proses perubahan tingkah laku sebagai hasil interaksi individu dengan lingkungannya dalam memenuhi kebutuhan hidupnya".

Menurut Nana Sudjana (2004: 22) "Prestasi belajar adalah kemampuan-kemampuan yang dimiliki siswa setelah ia menerima pengalaman belajarnya", sedangkan menurut Tohirin (2008: 151), "Prestasi belajar adalah apa yang telah dicapai oleh siswa setelah melakukan kegiatan belajar". Pencapaian prestasi belajar atau hasil belajar merujuk kepada aspek-aspek kognitif, afektif, dan psikomotor.

Pengertian Akuntansi, menurut Kardiman (2009: 2), “Akuntansi adalah sebuah sistem informasi, yaitu sebuah sistem yang menghasilkan informasi keuangan yang berdasarkan informasi tersebut dapat dilakukan penilaian dan keputusan yang tepat bagi para pemakainya". Menurut Haryono Jusup (2005: 5), "Akuntansi adalah proses pencatatan, penggolongan, peringkasan, pelaporan, dan penganalisaan data keuangan suatu organisasi".

Berdasarkan penjelasan di atas, maka dapat disimpulkan bahwa Prestasi Belajar Akuntansi adalah suatu hasil yang diperoleh siswa setelah melakukan kegiatan belajar berupa penguasaan pengetahuan dan keterampilan terhadap mata pelajaran akuntansi yang dibuktikan dengan hasil tes atau ujian yang dinyatakan dalam bentuk angka atau nilai yang merupakan kriteria keberhasilan seseorang dalam proses belajar akuntansi.

\section{Pengertian Persepsi Siswa tentang Mata Pelajaran Akuntansi}

Menurut Bimo Walgito (2010: 99) "Persepsi adalah suatu proses yang didahului oleh penginderaan, yaitu merupakan proses diterimanya stimulus oleh individu melalui alat indera atau juga disebut proses sensoris". Pendapat yang lain yaitu pendapat dari Slameto (2010: 102) yang mengemukakan pendapatnya bahwa "Persepsi adalah proses yang menyangkut masuknya pesan atau informasi ke dalam otak manusia". Selanjutnya Sugihartono (2007: 8) menyatakan "Persepsi merupakan proses untuk menerjemahkan atau menginterpretasi stimulus yang masuk dalam alat indera".

Berdasarkan beberapa pendapat para ahli tentang pengertian persepsi di atas, maka dapat diambil kesimpulan bahwa yang dimaksud dengan persepsi adalah suatu tanggapan tentang masuknya pesan/informasi langsung seseorang atau mengorganisasi, menafsirkan terhadap sesuatu hal yang dilihat, didengar, dirasakan yang menarik perhatiannya melalui alat indera. Jadi, Persepsi Siswa tentang Mata Pelajaran Akuntansi merupakan tanggapan atau penilaian siswa atas segala sesuatu yang berkaitan dengan proses pembelajaran akuntansi melalui inderanya yang bersifat subjektif. Tanggapan atau penilaian tentang mata pelajaran Akuntansi pada setiap siswa dapat berbeda-beda karena dipengaruhi oleh perhatian, rangsangan, nilai-nilai dan pengalaman yang dimiliki siswa.

\section{Pengertian Perhatian Orang Tua}

Menurut Sumadi Suryabrata (2006: 14) "Perhatian diartikan sebagai banyak sedikitnya kesadaran yang menyertai aktivitas yang sedang 
dilakukan". Menurut Bimo Walgito (2010: 110) "Perhatian merupakan pemusatan atau konsentrasi dari seluruh aktivitas individu yang ditujukan kepada suatu objek atau sekelompok objek". Slameto (2010: 105) "Perhatian adalah kegiatan yang dilakukan seseorang dalam hubungannya dengan pemilihan rangsangan yang datang dari lingkungannya".

Dalam Kamus Besar Bahasa Indonesia (2005: 802) "Orang tua adalah ayah dan ibu kandung, orang yang dianggap tua (cerdik, pandai, ahli), orang yang dihormati (disegani) dikampung". Orang tua yang dimaksud dalam penelitian di sini adalah ayah dan ibu atau wali.

Berdasarkan beberapa pendapat di atas, dapat diartikan bahwa Perhatian Orang Tua adalah usaha yang dilakukan oleh orang tua dalam memenuhi kebutuhan anaknya baik kebutuhan fisik, psikis maupun sosial.

\section{B. Metode Penelitian}

\section{Tempat dan Waktu Penelitian}

Penelitian ini dilaksanakan di MAN Tempel yang beralamatkan di Jalan Magelang Km.17, Margorejo, Ngosit, Tempel, Sleman, Yogyakarta. Adapun waktu penelitian dilaksanakan pada bulan Desember-Maret 2013.

\section{Jenis Penelitian}

Penelitian ini adalah jenis penelitian ex-post facto yaitu suatu penelitian yang dilakukan untuk meneliti peristiwa yang telah terjadi kemudian merunut ke belakang melalui data tersebut untuk menentukan faktor-faktor yang mendahului atau menentukan sebab-sebab yang mungkin atas peristiwa yang diteliti (Sugiyono, 2009: 7). Ditinjau dari tujuannya, penelitian ini merupakan penelitian kausal komparatif.

\section{Populasi Penelitian}

"Populasi adalah wilayah generalisasi yang terdiri atas: obyek/subyek yang mempunyai kualitas dan karakteristik tertentu yang ditetapkan dalam penelitian ini untuk dipelajari dan kemudian ditarik kesimpulannya" (Sugiyono, 2010: 117). Populasi dalam penelitian ini adalah siswa kelas XI IPS MAN Tempel Tahun Ajaran 2012/2013 yang berjumlah 80 siswa. Adapun perinciannya sebagai berikut:

Tabel Jumlah Populasi Penelitian

\begin{tabular}{|c|c|c|}
\hline No. & Kelas & Jumlah \\
\hline 1. & XI IPS 1 & 26 \\
\hline 2. & XI IPS 2 & 25 \\
\hline 3. & XI IPS 3 & 28 \\
\hline & h Siswa & 79 \\
\hline
\end{tabular}

\section{Teknik Pengumpulan Data}

\section{a. Angket/Kuesioner}

Angket ini digunakan untuk mengumpulkan data tentang Persepsi Siswa tentang Mata Pelajaran Akuntansi dan Perhatian Orang Tua. Dalam memperoleh data tersebut dilakukan dengan menyebar angket kepada subjek secara langsung. 


\section{b. Dokumentasi}

Dokumentasi ini digunakan untuk mengumpulkan data tentang Prestasi Belajar Akuntansi. Prestasi Belajar Akuntansi dapat diketahui melalui rata-rata dari nilai Ujian Tengah Semester (UTS) dan Ujian Akhir Semester (UAS) gasal tahun ajaran 2012/2013.

\section{Instrumen Penelitian}

\section{a. Kisi-kisi Instrumen}

Kisi-kisi instrumen variabel Persepsi Siswa tentang Mata Pelajaran Akuntansi meliputi: harapan dan kesiapan siswa, proses penyeleksian stimulus mata pelajaran Akuntansi pada siswa, penarik perhatian siswa dari dalam diri, penarik perhatian siswa dari luar, kondisi lingkungan atau situasi saat pelajaran Akuntansi diberikan. Kisi-kisi instrumen untuk variabel Perhatian Orang Tua adalah: Memberi kebebasan, memberi penghargaan dan hukuman, menyediakan fasilitas belajar, membantu kesulitan dalam belajar, memberi contoh/teladan.

\section{b. Uji Coba Instrumen}

uji coba instrumen akan dilakukan pada siswa kelas XI IPS MAN Pakem sejumlah 36 siswa.

\section{1) Uji Validitas Instrumen}

$$
r_{x y}=\frac{\mathrm{N} \sum \mathrm{XY}-\left(\sum \mathrm{X}\right)\left(\sum \mathrm{Y}\right)}{\sqrt{\left\{N \sum X^{2}-\left(\sum X\right)^{2}\right\}\left\{N \sum Y^{2}-\left(\sum Y\right)^{2}\right\}}}
$$

(Suharsimi, 2010: 317)

Tabel Hasil Uji Validitas Instrumen

\begin{tabular}{|c|c|c|c|c|}
\hline Variabel & $\begin{array}{c}\text { Jumlah Butir } \\
\text { Awal }\end{array}$ & $\begin{array}{c}\text { Jumlah Butir } \\
\text { Gugur }\end{array}$ & $\begin{array}{c}\text { No. Butir } \\
\text { Gugur }\end{array}$ & $\begin{array}{c}\text { Jumlah Butir } \\
\text { Valid }\end{array}$ \\
\hline X1 & 26 & 3 & $1,19,20$ & 23 \\
\hline X2 & 25 & 3 & $8,13,14$ & 22 \\
\hline
\end{tabular}

\section{2) Uji Reliabilitas}

Uji reliabilitas instrumen dimaksudkan untuk mengetahui derajat konsistensi (keajegan) suatu alat ukur.

$$
r_{11=\left(\frac{k}{k-1}\right)}\left(1-\frac{\sum \sigma_{b}^{2}}{\sigma_{t}^{2}}\right)
$$

(Suharsimi, 2010: 239)

Tabel Hasil Uji Reliabilitas Instrumen

\begin{tabular}{|c|l|c|c|}
\hline No. & \multicolumn{1}{|c|}{ Instrumen untuk Variabel } & $\begin{array}{c}\text { Koefisien Alfa } \\
\text { Cronbach's }\end{array}$ & $\begin{array}{c}\text { Keterangan } \\
\text { Reliabilitas }\end{array}$ \\
\hline 1. & $\begin{array}{l}\text { Persepsi Siswa tentang Mata } \\
\text { Pelajaran Akuntansi (X1) }\end{array}$ & 0,901 & Sangat Tinggi \\
\hline 2. & Perhatian Orang Tua (X2) & 0,891 & Sangat Tinggi \\
\hline
\end{tabular}

\section{Teknik Analisis Data}

a. Uji Prasyarat Analisis

\section{1) Uji Linearitas}


Uji linearitas digunakan untuk mengetahui apakah masingmasing variabel bebas mempunyai hubungan linear atau tidak dengan variabel terikatnya.

$$
F_{\text {reg }}=\frac{R K_{\text {reg }}}{R K_{\text {res }}}
$$

(Sutrisno Hadi, 2004: 13)

Hasil $F_{\text {hitung }}$ dikonsultasikan dengan $F_{\text {tabel }}$ dengan signifikansi 5\%. Jika $F_{\text {hitung }} \leq \mathrm{F}_{\text {tabel }}$ maka regresi dinyatakan linear, sebaliknya jika $\mathrm{F}_{\text {hitung }}>\mathrm{F}_{\text {tabel }}$ maka regresi dinyatakan tidak berbentuk linear.

2) Uji Multikolinearitas

Uji multikolinearitas dilakukan untuk mengetahui terjadi tidaknya multikolinearitas antara variabel bebas yang satu dengan variabel bebas lainnya.

$$
r_{x y}=\frac{\mathrm{N} \sum \mathrm{XY}-\left(\sum \mathrm{X}\right)\left(\sum \mathrm{Y}\right)}{\sqrt{\left.\left\{N \sum X^{2}-\left(\sum X\right)^{2}\right\} N \sum Y^{2}-\left(\sum Y\right)^{2}\right\}}}
$$

(Suharsimi, 2010: 213)

Jika $r_{\text {hitung }} \leq 0,800$ maka tidak terjadi multikolinearitas antarvariabel independen maka uji regresi ganda tidak dapat dilanjutkan, tetapi jika $\boldsymbol{r}_{\text {hitung }}>0,800$ maka terjadi multikolinearitas antarvariabel independen maka uji regresi ganda dapat dilanjutkan.

\section{b. Uji Hipotesis}

\section{1) Analisis Regresi Sederhana}

Teknik ini digunakan untuk menguji hipotesis pertama dan kedua, yaitu untuk mengetahui pengaruh variabel bebas terhadap variabel terikat secara sendiri-sendiri. Langkah-langkah yang ditempuh dalam analisis regresi sederhana adalah: persamaan garis regresi, mencari koefisien korelasi, koefisien determinan, keberartian regresi sederhana dengan uji t.

\section{2) Analisis Regresi Ganda}

Teknik ini digunakan menguji hipotesis ketiga, yaitu untuk mengetahui besarnya pengaruh variabel bebas secara bersamabersama terhadap variabel terikat. Dengan teknik ini dapat diketahui koefisien korelasi ganda antara variabel bebas dengan variabel terikat, koefisien determinan, sumbangan relatif serta sumbangan efektif masing-masing variabel terhadap variabel terikat.

\section{Hasil Penelitian Dan Pembahasan}

\section{Hasil Analisis Data}

\section{a. Variabel Prestasi Belajar Akuntansi}

Data mengenai variabel Prestasi Belajar Akuntansi siswa dalam penelitian ini diperoleh melalui dokumentasi yaitu perolehan rata-rata nilai Ujian Tengah Semester (UTS), dan Ujian Akhir Semester (UAS) semester gasal. Dari data yang terkumpul diketahui bahwa skor tertinggi yang diperoleh siswa adalah 92 dan skor terendah yang diperoleh siswa adalah 68. Setelah dianalisis menggunakan SPSS Statistics 20.00 for Windows diketahui bahwa nilai Mean sebesar 77,7595; Median sebesar 78,0000; Mode sebesar 69,00; dan Standar Deviasi sebesar 7,29105. 
Untuk mengetahui jumlah kelas interval digunakan rumus Sturges (Sturgess Rule), yaitu jumlah kelas interval $=1+3,3 \log \mathrm{n}$, maka dapat diketahui jumlah kelas interval $=1+3,3 \log 79$ sebesar 7 (pembulatan). Rentang data sebesar $92-68=24$. Dengan diketahuinya rentang data maka dapat diperoleh panjang kelas interval masing-masing kelompok yaitu 24/7 $=3,5$. Frekuensi kecenderungan variabel Prestasi Belajar Akuntansi kategori belum tuntas sebanyak 58 siswa $(73,42 \%)$, sedangkan kategori tuntas sebanyak $21(26,58 \%)$.

\section{b. Variabel Persepsi Siswa tentang Mata Pelajaran Akuntansi}

Data mengenai variabel Persepsi Siswa tentang Mata Pelajaran Akuntansi $\left(\mathrm{X}_{1}\right)$ diukur melalui angket dengan 23 butir pernyataan. Berdasarkan data yang diperoleh dari kuesioner/lembar angket yang disebarkan kepada 79 responden menunjukkan bahwa variabel Persepsi Siswa tentang Mata Pelajaran Akuntansi $\left(\mathrm{X}_{1}\right)$ diperoleh skor tertinggi sebesar 76 dari skor tertinggi yang mungkin dicapai sebesar $(4 \times 23)=92$ dan skor terendah sebesar 35 dari skor terendah yang mungkin dicapai (1 $\mathrm{x} 23)=23$. Dari skor tersebut kemudian dianalisis dengan menggunakan SPSS Statistics 20.00 for Windows diperoleh harga Mean (M) sebesar 54,9747; Median (Me) sebesar 53,0000; Mode sebesar 45,00; dan Standar Deviasi sebesar 10,97664. Untuk mengetahui jumlah kelas interval digunakan rumus, yaitu jumlah kelas interval $=1+3,3 \log \mathrm{n}$, maka dapat diketahui jumlah kelas interval $=1+3,3 \log 79$ sebesar 7 (pembulatan). Rentang data sebesar $76-35=41$. Dengan diketahuinya rentang data maka dapat diperoleh panjang kelas interval masing-masing kelompok yaitu $41 / 7=6$ (pembulatan). Frekuensi kecenderungan variabel Persepsi Siswa tentang Mata Pelajaran Akuntansi menunjukkan 9 siswa $(11,39 \%)$ yang berada dalam kategori sangat baik, 24 siswa $(30,38 \%)$ dalam kategori baik, 25 siswa $(31,65 \%)$ berada dalam kategori buruk dan 21 siswa (26,58\%) dalam kategori sangat buruk.

\section{c. Variabel Perhatian Orang Tua}

Data mengenai variabel Perhatian Orang Tua $\left(\mathrm{X}_{2}\right)$ diukur melalui kuesioner/ lembar angket dengan 22 butir pernyataan. Berdasarkan data yang diperoleh dari kuesioner/lembar angket yang disebarkan kepada 79 responden menunjukkan bahwa variabel Perhatian Orang Tua $\left(\mathrm{X}_{2}\right)$ diperoleh skor tertinggi sebesar 75 dari skor tertinggi yang mungkin dicapai sebesar $(4 \times 22)=88$ dan skor terendah sebesar 35 dari skor terendah yang mungkin dicapai $(1 \times 22)=22$. Dari skor tersebut kemudian dianalisis dengan menggunakan SPSS Statistics 20.00 for Windows diperoleh harga Mean (M) sebesar 56,3038; Median (Me) sebesar 59,0000; Mode sebesar 60,00; dan Standar Deviasi sebesar 10,28237. Untuk mengetahui jumlah kelas interval digunakan rumus, yaitu jumlah kelas interval $=1+3,3 \log \mathrm{n}$, maka dapat diketahui jumlah kelas interval $=1+3,3 \log 79$ sebesar 7 (pembulatan). Rentang data sebesar $75-35=40$. Dengan diketahuinya rentang data maka dapat diperoleh panjang kelas interval masing-masing kelompok yaitu 40/7 = 6 (pembulatan). Frekuensi kecenderungan variabel Perhatian Orang Tua menunjukkan 18 siswa $(22,79 \%)$ yang berada dalam kategori sangat 
baik, 19 siswa $(24,05 \%)$ dalam kategori baik, 30 siswa $(37,97 \%)$ dalam kategori buruk, dan 12 siswa $(15,19 \%)$ dalam kategori sangat buruk.

\section{Hasil Uji Prasyarat Analisis}

\section{a. Uji Linearitas}

Uji linearitas dalam penelitian ini dilakukan antara masing-masing variabel bebas dengan variabel terikat terjadi linear atau tidak.

Tabel Rangkuman Hasil Uji Linearitas

\begin{tabular}{|c|c|c|c|c|c|c|}
\hline \multirow{2}{*}{ No. } & \multicolumn{2}{|c|}{ Variabel } & \multirow{2}{*}{$F_{\text {hitung }}$} & $F_{\text {tabel }}$ & Sig. & Kesimpulan \\
\cline { 2 - 6 } & Bebas & Terikat & & & & \\
\hline 1. & $\mathrm{X}_{1}$ & $\mathrm{Y}$ & 1,165 & 1,695 & 0,314 & Linear \\
\hline 2. & $\mathrm{X}_{2}$ & $\mathrm{Y}$ & 1,051 & 1,70 & 0,429 & Linear \\
\hline
\end{tabular}

\section{b. Uji Multikolinearitas}

Uji multikolinearitas dilakukan untuk menguji apakah antar variabel bebas terjadi multikolinearitas atau tidak. Syarat tidak terjadinya multikolinearitas yaitu jika harga interkorelasi antarvariabel bebas < 0,800 .

\section{Hasil Uji Hipotesis Penelitian}

\section{a. Pengujian Hipotesis Pertama} sederhana.

Pengujian hipotesis pertama menggunakan analisis regresi

Tabel Rangkuman Hasil Uji Regresi Sederhana $\mathrm{X}_{1}-\mathrm{Y}$

\begin{tabular}{|c|c|c|c|c|c|c|c|c|c|}
\hline \multicolumn{2}{|c|}{ Variabel } & \multicolumn{2}{|c|}{ Harga $\mathrm{r}$ dan $\mathrm{r}^{2}$} & \multicolumn{2}{|c|}{ Harga $\mathrm{N}$} & \multirow{2}{*}{ Koef. } & Konst. & Sig. & Ket. \\
\cline { 2 - 5 } & $\mathrm{r}_{\mathrm{x} 1 \mathrm{y}}$ & $\mathrm{r}_{\mathrm{x} 1 \mathrm{y}}$ & $\mathrm{t}_{\text {hitung }}$ & $\mathrm{t}_{\text {tabel }}$ & & \\
\hline $\mathrm{X}_{1}$ & $\mathrm{Y}$ & 0,459 & 0,210 & 4,528 & 1,994 & 0,305 & 61,015 & 0,000 & $\begin{array}{c}\text { Positif } \\
\text { Signifikan }\end{array}$ \\
\hline
\end{tabular}

1) Persamaan Garis Regresi Linier

$$
\mathrm{Y}=0,305 \mathrm{X}_{1}+61,015
$$

Persamaan tersebut menunjukan bahwa nilai koefisien $\mathrm{X}_{1}$ sebesar 0,305 yang berarti apabila Persepsi Siswa tentang Mata Pelajaran Akuntansi $\left(\mathrm{X}_{1}\right)$ meningkat 1 poin maka Prestasi Belajar Akuntansi (Y) akan meningkat 0,305 poin.

2) Koefisien Korelasi Sederhana (r)

Berdasarkan hasil analisis data diperoleh harga $r$ positif sebesar 0,459, berarti terdapat pengaruh positif Persepsi Siswa tentang Mata Pelajaran Akuntansi $\left(\mathrm{X}_{1}\right)$ terhadap Prestasi Belajar Akuntansi (Y). Dengan demikian dapat dikatakan bahwa semakin baik Persepsi Siswa tentang Mata Pelajaran Akuntansi maka Prestasi Belajar Akuntansi akan semakin tinggi.

3) Koefisien Determinasi $\left(\mathrm{r}^{2}\right)$

Berdasarkan hasil analisis data dengan menggunakan SPSS Statistics 20.00 for Windows menunjukkan $\mathrm{r}^{2}$ sebesar 0,210, berarti bahwa Persepsi Siswa tentang Mata Pelajaran Akuntansi mampu mempengaruhi 21,0\% perubahan pada Prestasi Belajar Akuntansi. Hal ini menunjukkan, masih ada 79,0\% faktor atau variabel lain yang mempengaruhi Prestasi Belajar Akuntansi selain Persepsi Siswa tentang Mata Pelajaran Akuntansi. 
4) Pengujian Signifikansi Regresi Sederhana dengan Uji t.

Berdasarkan hasil analisis diperoleh nilai signifikansi t untuk variabel Persepsi Siswa tentang Mata Pelajaran Akuntansi harga thitung sebesar 4,528 lebih besar dari $t_{\text {tabel }}$ sebesar 1,994 (pada taraf signifikansi 5\%) yang berarti pengaruh Persepsi Siswa tentang Mata Pelajaran Akuntansi terhadap Prestasi Belajar Akuntansi signifikan.

\section{b. Pengujian Hipotesis Kedua}

Pengujian hipotesis menggunakan analisis regresi sederhana.

Tabel Rangkuman Hasil Uji Regresi Sederhana $\mathrm{X}_{2}-\mathrm{Y}$

\begin{tabular}{|c|c|c|c|c|c|c|c|c|c|}
\hline \multirow{2}{*}{\multicolumn{2}{|c|}{ Variabel }} & \multicolumn{2}{|c|}{ Harga $r$ dan $r^{2}$} & \multicolumn{2}{|c|}{ Harga t } & \multirow{2}{*}{ Koef. } & \multirow{2}{*}{ Konst. } & \multirow{2}{*}{ Sig. } & \multirow{2}{*}{ Ket. } \\
\hline & & $r_{x 1 y}$ & $\mathrm{r}_{\mathrm{x} 1 \mathrm{y}}^{2}$ & $\mathrm{t}_{\text {hitung }}$ & $t_{\text {tabel }}$ & & & & \\
\hline$X_{2}$ & $\mathrm{Y}$ & 0,378 & 0,143 & 3,585 & 1,994 & 0,268 & 62,659 & 0,001 & $\begin{array}{c}\text { Positif } \\
\text { Signifikan }\end{array}$ \\
\hline
\end{tabular}

1) Persamaan Garis Regresi Linier

$$
\mathrm{Y}=0,268 \mathrm{X}_{2}+62,659
$$

Persamaan tersebut menunjukkan bahwa nilai koefisien $\mathrm{X}_{2}$ sebesar 0,268 yang berarti apabila Perhatian Orang Tua $\left(\mathrm{X}_{2}\right)$ meningkat 1 poin maka Prestasi Belajar Akuntansi (Y) akan meningkat 0,268 poin.

2) Koefisien Korelasi Sederhana (r)

Berdasarkan hasil analisis data diperoleh harga $\mathrm{r}$ positif sebesar 0,378, berarti terdapat pengaruh positif Perhatian Orang Tua $\left(\mathrm{X}_{2}\right)$ terhadap Prestasi Belajar Akuntansi (Y). Dengan demikian dapat dikatakan bahwa semakin baik Perhatian Orang Tua maka Prestasi Belajar Akuntansi akan semakin tinggi.

3) Koefisien Determinasi $\left(r^{2}\right)$

Berdasarkan hasil analisis data dengan menggunakan SPSS Statistics 20.00 for Windows menunjukkan $\mathrm{r}^{2}$ sebesar 0,143, berarti bahwa Perhatian Orang Tua mampu mempengaruhi 14,3\% perubahan pada Prestasi Belajar Akuntansi. Hal ini menunjukkan, masih ada 85,7\% faktor atau variabel lain yang mempengaruhi Prestasi Belajar Akuntansi selain Perhatian Orang Tua.

4) Pengujian Signifikansi Regresi Sederhana dengan Uji t.

Berdasarkan hasil analisis diperoleh nilai signifikansi t untuk variabel Persepsi Siswa tentang Mata Pelajaran Akuntansi harga thitung sebesar 3,585 lebih besar dari $t_{\text {tabel }}$ sebesar 1,990 (pada taraf signifikansi 5\%) yang berarti pengaruh Perhatian Orang Tua terhadap Prestasi Belajar Akuntansi signifikan.

\section{c. Pengujian Hipotesis Ketiga}

Pengujian hipotesis ketiga menggunakan analisis linear ganda $\left(\mathrm{X}_{1}\right.$ dan $\mathrm{X}_{2}-\mathrm{Y}$ ).

Tabel Rangkuman Hasil Uji Regresi Ganda

\begin{tabular}{|c|c|c|c|c|c|c|c|c|c|}
\hline \multirow{2}{*}{ Variabel } & \multicolumn{2}{|c|}{ Harga $\mathrm{R}$ dan $\mathrm{R}^{2}$} & \multicolumn{2}{|c|}{ Harga $\mathrm{F}$} & \multirow{2}{*}{ Koef. } & \multirow{2}{*}{ Konst. } & \multirow{2}{*}{ Sig. } & \multirow{2}{*}{ Ket. } \\
\cline { 2 - 9 } & $\mathrm{R}_{\mathrm{y}(1,2)}$ & $\mathrm{R}_{\mathrm{y}(1,2)}$ & $\mathrm{F}_{\text {hitung }}$ & $\mathrm{F}_{\text {tabel }}$ & & & \\
\hline $\mathrm{X}_{1}$ & $\mathrm{Y}$ & 0,558 & 0,312 & 17,209 & 3,13 & 0,228 & 49,785 & 0,000 & $\begin{array}{c}\text { Positif } \\
\text { Signifikan }\end{array}$ \\
$\mathrm{X}_{2}$ & & & & & 0,275 & & & \\
\hline
\end{tabular}

1) Persamaan Garis Regresi Dua Prediktor

$$
\mathrm{Y}=0,275 \mathrm{X}_{1}+0,228 \mathrm{X}_{2}+49,785
$$

Persamaan tersebut menunjukan bahwa jika: 
a. Nilai Persepsi Siswa tentang Mata Pelajaran Akuntansi $\left(\mathrm{X}_{1}\right)$ naik 1 poin, nilai Perhatian Orang Tua $\left(\mathrm{X}_{2}\right)$ tetap maka Prestasi Belajar Akuntansi (Y) akan meningkat 0,275 poin.

b. Nilai Perhatian Orang Tua $\left(\mathrm{X}_{2}\right)$ naik 1 poin, nilai Persepsi Siswa tentang Mata Pelajaran Akuntansi $\left(\mathrm{X}_{1}\right)$ tetap maka Prestasi Belajar Akuntansi (Y) akan meningkat 0,228 poin.

2) Koefisien Korelasi Ganda (R)

Berdasarkan perhitungan dengan memanfaatkan program SPSS Statistics 20.00 for Windows diperoleh hasil $\mathrm{R}_{\mathrm{y}(1,2)}$ sebesar 0,558 menunjukkan hasil positif yang berarti hubungan variabel Persepsi Siswa tentang Mata Pelajaran Akuntansi dan Perhatian Orang Tua secara bersama-sama dengan variabel Prestasi Belajar Akuntansi adalah positif.

3) Koefisien Determinasi $\left(R^{2}\right)$

Berdasarkan hasil analisis data dengan menggunakan SPSS Statistics 20.00 for Windows menunjukkan sebesar 0,312 berarti bahwa Persepsi Siswa tentang Mata Pelajaran Akuntansi dan Perhatian Orang Tua secara bersama-sama mampu mempengaruhi $31,2 \%$ perubahan pada Prestasi Belajar Akuntansi. Hal ini menunjukkan, masih ada $68,8 \%$ faktor atau variabel lain yang mempengaruhi Prestasi Belajar Akuntansi selain Persepsi Siswa tentang Mata Pelajaran Akuntansi dan Perhatian Orang Tua.

4) Pengujian Signifikansi Korelasi Ganda dengan uji $F$

Berdasarkan hasil analisis diperoleh nilai signifikansi $\mathrm{F}$ sebesar

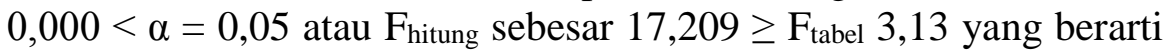
pengaruh variabel Persepsi Siswa tentang Mata Pelajaran Akuntansi dan Perhatian Orang Tua secara bersama-sama terhadap Prestasi Belajar Akuntansi adalah signifikan.

5) Sumbangan Relatif dan Sumbangan Efektif

Tabel Ringkasan Hasil Perhitungan Sumbangan Relatif dan Sumbangan Efektif

\begin{tabular}{|c|c|c|c|}
\hline \multirow{2}{*}{ No. } & \multicolumn{2}{|}{ Nama Variabel } & \multicolumn{2}{|c|}{ Sumbangan } \\
\cline { 3 - 4 } & Relatif $(\%)$ & Efektif (\%) \\
\hline 1. & $\begin{array}{l}\text { Persepsi Siswa tentang Mata } \\
\text { Pelajaran Akuntansi }\left(\mathrm{X}_{1}\right)\end{array}$ & $60,95 \%$ & $19,02 \%$ \\
\hline 2. & Perhatian Orang Tua $\left(\mathrm{X}_{2}\right)$ & $39,05 \%$ & $12,18 \%$ \\
\hline
\end{tabular}

Sumber: Data Primer yang Diolah

Berdasarkan hasil analisis yang tercantum dalam tabel di atas dapat diketahui bahwa Sumbangan Relatif Persepsi Siswa tentang Mata Pelajaran Akuntansi 60,95\% dan Perhatian Orang Tua 39,05\%. Sedangkan Sumbangan Efektif variabel Persepsi Siswa tentang Mata Pelajaran Akuntansi 19,02\% dan Perhatian Orang Tua 12,18\%. Secara bersama-sama variabel Persepsi Siswa tentang Mata Pelajaran Akuntansi dan Perhatian Orang Tua memberikan Sumbangan Efektif sebesar 31,2\% terhadap pencapaian Prestasi Belajar Akuntansi dan sebesar 68,8\% diberikan oleh variabelvariabel lain yang tidak dibahas pada penelitian ini. 


\section{Pembahasan}

a. Pengaruh Persepsi Siswa tentang Mata Pelajaran Akuntansi terhadap Prestasi Belajar Akuntansi

Berdasarkan hasil analisis dengan menggunakan bantuan komputer program SPSS Statistics 20.00 for Windows diperoleh harga $\mathrm{r}_{\mathrm{x} 1 \mathrm{y}}$ positif sebesar 0,459 berarti Persepsi Siswa tentang Mata Pelajaran Akuntansi berpengaruh positif terhadap Prestasi Belajar Akuntansi. Sedangkan harga koefisien determinasi $\left(\mathrm{r}^{2}{ }_{\mathrm{x} 1 \mathrm{y}}\right)$ sebesar 0,210 menunjukkan bahwa Persepsi Siswa tentang Mata Pelajaran Akuntansi memiliki kontribusi pengaruh terhadap Prestasi Belajar Akuntansi sebesar 21,0\%. Setelah dilakukan uji t diperoleh thitung sebesar 4,528 lebih besar dari tabel pada taraf signifikansi 5\% sebesar 1,990 atau nilai signifikansi sebesar 0,000< $\alpha=0,05$ yang berarti pengaruh Persepsi Siswa tentang Mata Pelajaran Akuntansi terhadap Prestasi belajar Akuntansi adalah signifikan. Dengan demikian dapat disimpulkan bahwa terdapat pengaruh positif dan signifikan Persepsi Siswa tentang Mata Pelajaran Akuntansi terhadap Prestasi Belajar Akuntansi.

b. Pengaruh Perhatian Orang Tua terhadap Prestasi Belajar Akuntansi

Berdasarkan hasil analisis dengan menggunakan bantuan komputer program SPSS Statistics 20.00 for Window diperoleh harga $\mathrm{r}_{\mathrm{x} 2 \mathrm{y}}$ positif sebesar 0378, berarti Perhatian Orang Tua berpengaruh positif terhadap Prestasi Belajar Akuntansi. Sedangkan harga koefisien determinasi $\left(\mathrm{r}_{\mathrm{x} 2 \mathrm{y}}^{2}\right)$ sebesar 0,143 menunjukkan bahwa Perhatian Orang Tua memiliki kontribusi pengaruh terhadap Prestasi Belajar Akuntansi sebesar 14,3\%. Setelah dilakukan uji $\mathrm{t}$ diperoleh $\mathrm{t}$ hitung sebesar 3,585 lebih besar dari $\mathrm{t}$ tabel pada taraf signifikansi $5 \%$ sebesar 1,990 atau nilai signifikansi sebesar $0,143<\alpha=0,05$ yang berarti pengaruh Perhatian Orang Tua terhadap Prestasi belajar Akuntansi adalah signifikan.

c. Pengaruh Persepsi Siswa tentang Mata Pelajaran Akuntansi dan Perhatian Orang Tua terhadap Prestasi Belajar Akuntansi

Berdasarkan hasil analisis dengan menggunakan bantuan komputer program SPSS Statistics 20.00 for Window diperoleh harga $\mathrm{r}_{\mathrm{x}(1,2) \mathrm{y}}$ positif sebesar 0,558 berarti Persepsi Siswa tentang Mata Pelajaran Akuntansi dan Perhatian Orang Tua berpengaruh positif terhadap Prestasi Belajar Akuntansi. Sedangkan harga koefisien determinasi $r^{2}{ }_{x(1,2) y}$ sebesar 0,312 menunjukkan bahwa Persepsi Siswa tentang Mata Pelajaran Akuntansi dan Perhatian Orang Tua memiliki kontribusi pengaruh terhadap Prestasi Belajar Akuntansi sebesar 31,2\%. Setelah dilakukan uji F diperoleh F hitung sebesar 17,209 lebih besar dari $\mathrm{F}$ tabel pada taraf signifikansi 5\% sebesar 3,12 atau nilai signifikansi sebesar $0,000<\alpha=0,05$ yang berarti pengaruh Persepsi Siswa tentang Mata Pelajaran Akuntansi dan Perhatian Orang Tua terhadap Prestasi belajar Akuntansi adalah signifikan. Dengan demikian dapat disimpulkan bahwa terdapat pengaruh positif dan signifikan Persepsi Siswa tentang Mata Pelajaran Akuntansi dan Perhatian Orang Tua secara bersama-sama terhadap Prestasi Belajar Akuntansi. Semakin baik Persepsi Siswa tentang Mata Pelajaran 
Akuntansi dan Perhatian Orang Tua maka semakin tinggi Prestasi Belajar Akuntansi.

\section{Penutup}

\section{Simpulan}

a. Terdapat pengaruh positif dan signifikan

Terdapat pengaruh positif dan signifikan Persepsi Siswa tentang Mata Pelajaran Akuntansi terhadap Prestasi Belajar Akuntansi Siswa Kelas XI IPS MAN Tempel Tahun Ajaran 2012/2013. Hal ini ditunjukkan dengan harga $r_{x 1 y}$ sebesar 0,459 dan $r_{x 1 y}^{2}$ sebesar 0,210, harga $t_{\text {hitung }}>t_{\text {tabel }}$ pada taraf signifikansi 5\% yaitu 4,528>1,994 dengan $\mathrm{N}=79$. Hal ini menunjukkan bahwa semakin baik Persepsi Siswa tentang Mata Pelajaran Akuntansi, maka akan semakin tinggi Prestasi Belajar Akuntansi, dan sebaliknya.

b. Terdapat pengaruh positif dan signifikan

Terdapat pengaruh positif dan signifikan Perhatian Orang Tua terhadap Prestasi Belajar Akuntansi Siswa Kelas XI IPS MAN Tempal Tahun Ajaran 2012/2013. Hal ini ditunjukkan dengan harga $r_{x 2 y}$ sebesar 0,378 dan $r_{x 2 y}^{2}$ sebesar 0,143 , harga $t_{\text {titung }}>t_{\text {tabel }}$ pada taraf signifikansi $5 \%$ yaitu 3,585 > 1,994 dengan $\mathrm{N}=79$. Hal ini menunjukkan bahwa semakin baik Perhatian Orang Tua maka akan semakin tinggi Prestasi Belajar Akuntansi, dan sebaliknya

c. Terdapat pengaruh positif dan signifikan

Terdapat pengaruh positif dan signifikan Persepsi Siswa tentang Mata Pelajaran Akuntansi dan Perhatian Orang Tua secara bersama-sama terhadap Prestasi Belajar Akuntansi Siswa Kelas XI IPS MAN Tempel Tahun Ajaran 2012/2013. Hal ini ditunjukkan dengan harga $\mathbf{R}_{\mathrm{x}(1,2) \mathrm{y}}$ sebesar 0,558 dan $\mathrm{R}_{\mathrm{x}(1,2) \text { y }}^{2}$ sebesar 0,312 , harga $\mathrm{F}_{\text {hitung }}>\mathrm{F}_{\text {tabel }}$ pada taraf signifikansi $5 \%$ dengan db 2;76 yaitu 17,209 >3,13. Hal ini menunjukkan bahwa semakin baik Persepsi Siswa tentang Mata Pelajaran Akuntansi dan Perhatian Orang Tua maka akan semakin tinggi pula Prestasi Belajar Akuntansi siswa.

\section{Saran}

Berdasarkan hasil penelitian di atas maka dapat diberikan saran-saran sebagai berikut:

1. Bagi Peneliti Selanjutnya

Penelitian ini memberikan informasi bahwa faktor Persepsi Siswa tentang Mata Pelajaran Akuntansi dan Perhatian Orang Tua secara bersama-sama berpengaruh terhadap Prestasi Belajar Akuntansi sebesar $31,2 \%$. Untuk itu perlu adanya penelitian lebih lanjut tentang faktorfaktor lain yang mempengaruhi Prestasi Belajar Akuntansi selain kedua faktor tersebut.

2. Bagi Siswa

Siswa sebaiknya disiplin terhadap jam belajar yang telah terbentuk. Tanpa menunggu ditegur, seharusnya siswa sadar dengan kebutuhan belajarnya. Di Sekolah, pada saat pelajaran berlangsung sebaiknya siswa 
memperhatikan penjelasan guru, tidak mengobrol dan bercanda dengan teman sebelahnya.

3. Bagi Orang Tua

Ketika anak sedang belajar sebaiknya orang tua mematikan televisi atau radio sehingga anak bisa berkonsentrasi dalam belajar, memberi pujian kepada anak juga perlu dilakukan untuk memperkuat semangat belajar anak. Hal lain yang bisa dilakukan sebagai wujud perhatian orang tua adalah menyediakan tempat belajar khusus untuk anak. Dengan demikian diharapkan Prestasi Belajar Siswa bisa meningkat.

4. Bagi Sekolah

Untuk meningkatkan Prestasi Belajar pada umumnya dan Prestasi Belajar Akuntansi pada khususnya sekolah diharapkan memberikan fasilitas yang menunjang dalam pembelajaran. Dari hasil kuesioner/lembar angket didapatkan bahwa persepsi negatif siswa yaitu bahwa mata pelajaran Akuntansi itu sulit dan membosankan, sehingga sekolah harus menyediakan sarana dan prasarana yang dapat digunakan oleh guru dalam penyampaian materi dengan lebih mudah dan menarik untuk siswanya.

\section{E. Daftar Pustaka}

Abu Ahmadi. (2008). Psikologi Belajar. Jakarta: Rineka Cipta.

Bimo Walgito. (2010). Pengantar Psikologi Umum. Yogyakarta: Andi Offset.

Binarko Agung Rahmanto. (2009). Hubungan antara Persepsi Siswa tentang Mata Pelajaran Akuntansi dan Penggunaan Media Pembelajaran dengan Prestasi Belajar Akuntansi Siswa Kelas XI IPS SMA Negeri 2 Banguntapan Bantul Yogyakarta Tahun Ajaran 2007/2008. Skripsi. Yogyakarta: FISE UNY.

Dalyono, M. (2009). Psikologi Pendidikan. Jakarta: PT Rineka Cipta.

Depdiknas. (2003). Undang-Undang Sistem Pendidikan Nasional. Diambil dari: http://www.inherent-dikti.net/files/sisdiknas.pdf, pada 20 Oktober 2012.

Deshi Veronika Revani. (2012). Pengaruh Perhatian Orang Tua dan Motivasi Belajar terhadap Prestasi Belajar Akuntansi Siswa Kelas X Program Keahlian Akuntansi SMK YPKK 2 Sleman Tahun Ajaran 2011/2012. Skripsi. Yogyakarta: FE UNY.

Dimyati dan Mudjiono. (2006). Belajar dan Pembelajaran. Jakarta: Rineka Cipta.

Djemari Mardapi. (2008). Teknik Penyusunan Intrumen Tes dan Nontes. Yogyakarta: Mitra Cendika.

Evi Munawaroh. (2010). Pengaruh Perhatian Orang Tua dan Kebiasaaan Belajar terhadap Prestasi Belajar Siklus Akuntansi Siswa Kelas X 
Program keahlian Akuntansi SMK YPKK 1 Sleman Tahun Ajaran 2009/2010. Skripsi. Yogyakarta: FISE UNY.

Haryono Jusup. (2005). Dasar-dasar Akuntansi. Yogyakarta: Bagian Penerbitan Sekolah Tinggi Ilmu Ekonomi YKPN.

Irwanto. (2002). Psikologi Umum. Jakarta: PT Prehalindo.

Ismani, dkk. (2009). Pedoman Penulisan Tugas Akhir. UNY: Jurusan Pendidikan Akuntansi.

Kardiman. (2009). Prinsip-prinsip Akuntansi 1. Jakarta: Yudhistira.

Muhibbin Syah. (2008). Psikologi Pendidikan dengan Pendekatan Baru. Edisi Revisi. Bandung: PT Remaja Rosdakarya.

Mustaqim. (2008). Psikologi Pendidikan. Semarang: Pustaka Pelajar Offset.

Nana Sudjana. (2004). Dasar-Dasar Proses Belajar Mengajar. Bandung: Sinar Baru Algesindo.

(2004). Penelitian dan Penilaian Pendidikan. Bandung: Sinar Baru Algesindo.

Nana Syaodih. (2009). Landasan Psikologi Pendidikan. Bandung: PT Remaja Rosdakarya

Singgih Dirgagunarso. (1996). Pengantar Psikologi. Jakarta: Mutiara Sumber Widia.

Slameto. (2010). Belajar dan Faktor-faktor yang Mempengaruhinya. Jakarta: PT Rineka Cipta.

Sugihartono. (2007). Psikologi Pendidikan. Yogyakarta: UNY Press.

Sugiyono. (2010). Metode Penelitian Pendidikan. Bandung: Alfabeta. (2009). Metode Penelitian Pendidikan Pendekatan Kuantitatif, Kualitatif dan $R \& D$. Bandung: Alfabeta.

Suharsimi Arikunto. (2007). Dasar-dasar Evaluasi Pendidikan. Jakarta: PT Bumi Aksara. . (2010). Prosedur Penelitian. Jakarta: PT Rineka Cipta.

Sumadi Suryabrata. (2006). Psikologi Pendidikan. Suatu Pendekatan Baru. Bandung: PT Remaja Rosdakarya.

Sutrisno Hadi. (2004). Analisis Regresi. Yogyakarta: Andi Offset.

Suwardjono. (2011). Teori Akuntansi. Yogyakarta: BPFE.

Taswan. (2008). Akuntansi Perbankan. Yogyakarta: Unit Penerbit dan PercetakanSekolah Tinggi Ilmu Manajemen YKPN. 